\title{
Colour Variants in the Bialowieża Population of the European Water Shrew
}

\author{
Stanisław FEDYK \& Stanisław BOROWSKI
}

\begin{abstract}
Fedyk S. \& Borowski S., 1980: Colour variants in the Białowieża popuiation of the European water shrew. Acta theriol., 25, 1: 3-24 [With 5 Tables, 7 Figs \& Plates I-II].

Trapping of Neomys fodiens (P e n n a n $t, 1771)(\mathrm{n}=1484)$ was carried out from 1946 to 1968 in ten forest ecosystems of the Białowieża National Park, and the animals caught examined for coat colour and the presence of dark badges on the ventral side of their fur. Only slight differences in frequency of the different colour forms were found in material obtained from different terrestrial ecosystems. These differences are, however, greater when 22 successive generations are compared: during the initial period of the studies lightcoloured form predominated, but latter their numbers gradually decreased, and as from generation XVI the frequency of the lightcoloured form increased. Individuals possessing an admixture of cinnamon colour in their coat also predominated during the first four generations (average $78 \%$ ) then as from generation $\mathrm{V}$ the frequency of this form fell below $40 \%$ and despite certain fluctuations did not exceed $40 \%$ up to the end of the study period. Frequencies of individuals with dark badges (spots and stripes) fluctuated within narrow limits. Analysis of the material points to the complicated character of inheritance of both the basic colour of the ventral side of the body and of dark badges in European water shrews.
\end{abstract}

[Mammals Res. Inst., Polish Acad. Sci., 17-230 Białowieża].

\section{INTRODUCTION}

The water shrew - Neomys fodiens (P e n n a $\mathrm{t}, 1771$ ) is characterized by a relatively great degree of variation in coat colour. This applies particularly to the ventral side of the fur, although there are also considerable differences in the colour of the back.

Dehnel (1950) found that all the kinds of coat colour described for this species are encountered in the Białowieża Primeval Forest. This applies both to coat colour and occurrence on the ventral side of the characteristic badges (round or oval dark spots on the throat and a dark stripes in the middle part of the underside). This variation has been described in far greater detail by B orowski (1973) on the basis of studies of a very large series of $N$. fodiens originating from the Bialowieża Primeval Forest. The author distinguished 12 shades of colour of the belly, and three additional colour characteristics i.e. dark spots on the throat, dark stripes on the belly and dark badges running trans- 
versely at the level of the fore legs.

Variation in coat colour in $N$. fodiens has also been described in other European populations: from Bavaria ( $\mathrm{K}$ a h m ann \& Röss ner, 1956) from France ( $\mathrm{G} \mathrm{ib} \mathrm{a} \mathrm{n,} \mathrm{1956)} \mathrm{from} \mathrm{Austria} \mathrm{(B} \mathrm{a} \mathrm{u} \mathrm{e} \mathrm{r,} \mathrm{1960)} \mathrm{and} \mathrm{from}$ Finland ( $\mathrm{S}$ k a re ń, 1973). In Western European populations less variation was generally found than in the water shrew from Białowieża Primeval Forest. This is probably due to the fact that the amount of material available was usually small, and consequently the rarer forms of coat patterns might not have appeared in them. There is thus no doubt that such variation is not of a local character, but applies to a wider region, as is confirmed by $\mathrm{Br}$ e e et al. (1963) in their review. L e h m a n n (1966), on the other hand, connects the occurrence of the dark forms of $N$. fodiens with the habitat. In his opinion the dark forms are more frequent in a wet marshy habitats.

The present paper relates to material collected for a period of over 20 years from the Białowieża National Park and used earlier on in the paper by Borowski (1973). Here the coat colour of Neomys fodiens has been considered from the aspect of biotope differences and also of variation taking place in time. Unfortunately the hitherto scanty data available on the genetic basis of coat colour in $N$. fodiens (D e hn e l, 1950; K a hmann \& R ös sn er, 1956; S e a r le, 1968) have not permitted in the present study of employing the appropriate genes, which would undoubtedly have made the study far more exact.

\section{MATERIAL AND METHODS}

The material for the present study consisted of 1484 individuals of $N$. fodiens trapped during the period from September 1946 to December 1968 in ten terrestrial ecosystems occuring in the Białowieża National Park. The numeration of these biotopes used in the subsequent part of this text, and their current names, are given in Table 1.

During the initial period, i.e. from 1946 to the end of 1950, the animals were trapped only in pitfalls placed on permanent areas with paths (Dehne l, 1950; Borowski \& Dehnel, 1952). During this period the trapping areas functioned in all the biotopes of the Białowieża National Park uninterruptedly throughout the whole period, and on this account material from this period has been treated separately. During the remaining period water shrews were caught in different types of trap in pathless areas which were frequently shifted. Trapping was not carried out simultaneously in all biotopes during this period, and consequently as from 1951 material was not collected systematically.

In all 22 generations were distinguished (see Takie 4). One generation consisted of young individuals caught during the year of birth and old individuals (overwintered) caught the following calendar year. 54 individuals of $N$. fodiens kept in the laboratory were also added. These individuals were not taken into con- 
sideration in B or ow ski's paper (1973), as the moulting process became disturbed during the time they were kept in the laboratory.

Both coat colour and occurrence of dark badges on the ventral side of the body were analyzed. A detailed description of these colour characteristics is given in the following section.

Table 1

Forest ecosystems of the Białowieża National Park.

\begin{tabular}{|c|c|c|}
\hline $\begin{array}{l}\text { No. of } \\
\text { biotopes }\end{array}$ & Scientific name & English name \\
\hline $\begin{array}{l}\text { I } \\
\text { II } \\
\text { III }\end{array}$ & $\begin{array}{l}\text { Peucedano-Pinetum } \\
\text { Peucedano-Pinetum typicum } \\
\text { Pino-Quercetum } \\
\quad \text { serratuletosum }\end{array}$ & $\begin{array}{l}\text { Continental pine forest } \\
\text { Continental pine forest, subboreal variety } \\
\text { Continental pine-oak mixed forest }\end{array}$ \\
\hline $\begin{array}{l}\text { IIIa } \\
\text { IV } \\
\text { V and Va } \\
\text { VI }\end{array}$ & $\begin{array}{l}\text { Calamagrostio-Quercetum } \\
\text { Vaccinio uliginosii-Pinetum } \\
\text { Tilio-Carpinetum typicum } \\
\text { Tilio-Carpinetum }\end{array}$ & $\begin{array}{l}\text { Central-European acidophilous oak forest } \\
\text { Continental bog pine forest } \\
\text { Deciduous forest, pure form }\end{array}$ \\
\hline $\begin{array}{l}\text { VII } \\
\text { VIII } \\
\text { IX }\end{array}$ & $\begin{array}{l}\quad \text { stachyetosum } \\
\text { Circaeo-Alnetum } \\
\text { Caricetalia } \\
\text { Hylaquarium }\end{array}$ & $\begin{array}{l}\text { Deciduous forest } \\
\text { Floodplain forest } \\
\text { Sedge bogs } \\
\text { Forest ponds }\end{array}$ \\
\hline
\end{tabular}

\section{DESCRIPTION OF CHARACTERISTICS EXAMINED}

\subsection{Coat Colour}

Borowski (1973), in analyzing the same material, distinguished 12 shades of ventral coat colour in the water shrew. In the present paper this detailed description of colour shades has been omitted, distinguishing only two classes of individuals: the light coloured form these are water shrews in which the fur on the ventral side of the body is a shade of light grey, in extreme cases individuals belonging to this class having silvery-white bellies (Plate I A and B), and the dark form - water shrews belonging to this class have fur on the ventral side of the body in different shades of brown, but the ventral side of the body is always lighted in colour than the dorsal side (Plate I C). In $N$. fodiens material extremely dark individuals are also encountered and in such cases there is no difference between the colour of the fur on the belly and back, and they are thus individuals of uniform colour (Plate I D) and in literature are sometimes defined as the melanistic form (cf. B re e et al., 1963). In addition the fur on the ventral side of the body may have an admixture of cinnamon coloured fur. Such specimens, with differing intensity of cinnamon colour, are encountered among the dark and light forms, except that in the dark forms, particularly dark brown, it is far more difficult to discover the admixture of cinnamon colour 
than in light-coloured individuals. Sometimes the cinnamon colour is so intense that it is impossible to determine whether the individual belongs to the light or dark form. It was consequently necessary to distinguish a separate class: the extreme cinnamon form.

\subsection{Additional Colour Badges}

In addition to the differences in colour described above, dark badges occur on the ventral side of the water shrew's body. Obviously it is impossible to determine the presence of these features in the extreme dark and extreme cinnamon-coloured forms. The dark places are: (1) dark spot, situated on the throat (cf. Plate I B, C and Plate II A, B and D), (2) dark stripe, running along the median ventral line (cf. Plate

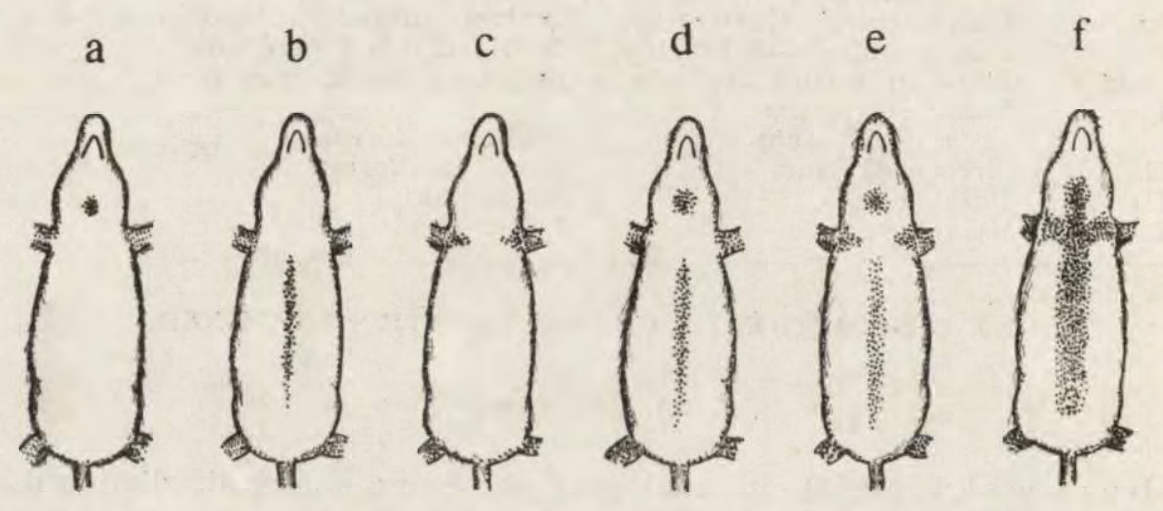

Fig. 1. Variations in arrangement of colour features (spot, stripe and badges under fore legs) on ventral side of the coat of Neomys fodiens.

(a) spot, (b) stripe, (c) badges under fore legs, (d) spot and stripe, (e) spot, stripe and badges under fore legs, (f) all three features fused to form one cross-shaped patch.

I B, C and Plate II) and (3) dark badges occurring at the level of the fore legs (cf. Plate I B and Plate II B). These last badges often fuse with the dorsal part of dark-coloured fur in wider or narrower bands running diagonally caudad. In West European populations in which this character is probably more frequent in occurrence and more strongly visible, individuals are encountered in which these badges fuse with the stripe on the belly, forming a Y-shaped badge (cf. Plate II D and $\mathrm{K}$ a h m a n $\mathrm{n}$ \& $\mathrm{R}$ össner, 1956).

Both the shade of colour and the area of all these badges vary (cf. Plates I and II). In some populations (cf. $\mathrm{Kahmann} \& \mathrm{R}$ össner, 1956; B a u e r, 1960) individuals in which all these three features are very strongly developed occur more frequently. A diagram is given in Fig. 1 showing combinations of all three features. 


\section{RESULTS}

\subsection{Differences Between Biotopes}

Material obtained during the period from 1946-1950 is the most suitable for comparisons of water shrews originating from various biotopes in the Białowieża National Park (Table 2). During this period the light-colour forms predominate (average $81 \%$ ). In different biotopes the frequencies of light-coloured forms vary from $70 \%$ (VI - Decıduous

Table 2

Frequency of occurrence in study biotopes of individuals of $N$. fodiens with given colour features on ventral side of the coat. Material from period 1946-1950, absolute numbers $(\mathrm{n})$ and \%

\begin{tabular}{|c|c|c|c|c|c|c|c|c|c|c|c|c|c|c|c|}
\hline \multirow[t]{2}{*}{ Biotopes } & \multirow[t]{2}{*}{$\mathrm{n}$} & \multicolumn{2}{|c|}{$\begin{array}{l}\text { Light } \\
\text { form }\end{array}$} & \multicolumn{2}{|c|}{$\begin{array}{c}\text { Cinnamon } \\
\text { form }\end{array}$} & \multirow{2}{*}{\multicolumn{2}{|c|}{$\begin{array}{l}\text { Extr. } \\
\text { cin. } \\
\text { form } \\
n \quad \%\end{array}$}} & \multicolumn{2}{|c|}{$\begin{array}{l}\text { Extr. } \\
\text { dark } \\
\text { form }\end{array}$} & \multicolumn{2}{|c|}{$\begin{array}{l}\text { Dark } \\
\text { stripe }\end{array}$} & \multicolumn{2}{|c|}{$\begin{array}{r}\text { Dark } \\
\text { spot }\end{array}$} & \multicolumn{2}{|c|}{$\begin{array}{r}\text { Badges } \\
\text { under } \\
\text { fore legs }\end{array}$} \\
\hline & & $\mathrm{n}$ & $\%$ & $\mathrm{n}$ & $\%$ & & & $\mathrm{n}$ & $\%$ & $\mathrm{n}$ & $\%$ & $\mathrm{n}$ & $\%$ & $\mathrm{n}$ & $\%$ \\
\hline & & & & & Dry & bio & topes & & & & & & & & \\
\hline I & 9 & 7 & 78 & 6 & 67 & - & - & - & - & 2 & 22 & 4 & 44 & - & - \\
\hline $\begin{array}{l}\text { II } \\
\text { III }\end{array}$ & 23 & 19 & 83 & 18 & 78 & - & - & 1 & 4 & 8 & 35 & 13 & 57 & 1 & 4 \\
\hline $\begin{array}{l}\text { IIIa } \\
\text { V }\end{array}$ & 22 & 19 & 86 & 19 & 86 & - & - & - & - & 7 & 32 & 8 & 36 & - & - \\
\hline Va & 18 & 16 & 89 & 13 & 72 & - & - & 1 & 6 & 4 & 22 & 9 & 50 & - & - \\
\hline VI & 43 & 30 & 70 & 30 & 70 & - & - & 2 & 5 & 11 & 26 & 11 & 26 & 2 & 5 \\
\hline $\begin{array}{l}\text { Totals } \\
\text { and Avgs }\end{array}$ & 115 & 91 & 79 & 86 & 75 & - & - & 4 & 3 & 32 & 28 & 55 & 48 & 3 & 3 \\
\hline & & & & & Wet & bio & topes & & & & & & & & \\
\hline VII & 23 & 17 & 74 & 20 & 87 & - & - & - & - & 8 & 35 & 14 & 61 & $=$ & - \\
\hline VIII & 44 & 34 & 77 & 38 & 86 & 3 & 7 & 2 & 4 & 16 & 36 & 19 & 43 & 2 & 5 \\
\hline IX & 261 & 218 & 83 & 203 & 78 & 2 & 1 & 4 & 1 & 76 & 29 & 133 & 51 & 5 & 2 \\
\hline IV & 75 & 59 & 79 & 61 & 81 & - & - & 4 & 5 & 28 & 37 & 43 & 57 & - & - \\
\hline $\begin{array}{l}\text { Totals } \\
\text { and Avgs } \\
\text { Totals and }\end{array}$ & 403 & 328 & 81 & 322 & 80 & 5 & 1 & 10 & 2 & 128 & 32 & 209 & 52 & 7 & 2 \\
\hline Averages & 518 & 419 & 81 & 408 & 79 & 5 & 1 & 14 & 3 & 160 & 31 & 264 & 51 & 10 & 2 \\
\hline
\end{tabular}

forest) to $89 \%$ (V - Deciduous forest - pure form), but differences between these biotopes ${ }^{1}$ are not significant $\left(\chi_{6}^{2}=6.901 ; P>0.3\right)$, even comparison of two extreme biotopes (V and VI) does not reveal statistically significant differences $\left(\gamma^{2}=2.502 ; P>0.1\right)$. Individuals in which the coat has an admixture of cinnamon colour also occur very frequently (average $79 \%$ ). The lowest values occur in Continental pine forests (I), the highest in Continental pine-oak mixed forests (III) and

${ }^{1}$ Biotopes I, II, III and IIIa were combined in one class - "Coniferous forests". 
on Sedge bogs (VIII), nevertheless comparison of all biotopes failed to reveal no significant differences $\left(\chi_{6}^{2}=5.441 ; P>0.3\right)$. Individuals of very intensive cinnamon colour (extreme cinnamon) were only encountered in wet biotopes, but no hasty conclusions should be drawn from this fact; the probability of occurrence of water shrews with an extreme cinnamon belly in dry biotopes (assuming that this form occurs equally frequently in dry and wet biotopes) is only 1.42 individuals out of 115 caught. The frequencies of extremely dark form (unicolour) are similar in wet and dry biotopes $\left(\chi_{1}^{2}=0.338 ; P>0.5\right)$.

The frequency of individuals with a stripe varies from $22 \%$ (biotopes I and V) to $37 \%$ (biotope IV), but comparisons of all biotopes do not reveal significant deviations $\left(\chi_{6}^{2}=3.832 ; P \approx 0.7\right)$. Far greater amplitude is exhibited by frequencies of individuals with dark spots $(36 \%$ - biotope III, $61 \%$ - biotope VII) (Table 2) but here also there are no significant differences between biotopes $\left(\chi_{6}^{2}=3.742 ; P>0.7\right)$.

Comparison of material originating from dry and wet biotopes $n_{1}=115$, $\mathrm{n}_{2}=403$, Table 2) also points to satisfactory homogeneity: for frequency of light- and dark coloured forms $\chi_{1}^{2}=0.295 ; P>0.5$, for frequencies of water shrews with admixture of cinnamon colour $\chi_{1}^{2}=0.584 ; P>0.3$, for frequencies of individuals with a stripe $\chi^{2}{ }^{2}=0.649 ; P>0.3$ and with spot $\chi_{1}^{2}=0.583 ; P>0.3$.

Similar comparisons were also made for the whole material $(n=1484)$ obtained during the period 1946-1968 (Table 3). In dry biotopes (I, II, III, IIIa, V, Va,VI) $51 \%$ of light-coloured individuals occur, and in wet biotopes (VII, VIII, IX and IV) $-58 \%$. This difference is statistically significant $\left(\chi_{1}^{2}=6.238 ; P<0.02\right)$.

On the other hand comparisons of the different dry biotopes (biotopes III, IIIa and V and Va were combined) reveal far greater differentiation $\left(\chi_{4}^{2}=27.981 ; P \ll 0.001\right)$. It was only in biotope VI that a smaller number of the light form of individuals was found in relation to expected values $(D=19.3$ with $\mathrm{n}=362$ ), while in the remaining dry biotopes only a minimum preponderance of light-coloured individuals was found. In two wet biotopes (VII and VIII), on the other hand, there was a preponderance of dark-coloured individuals, but in biotopes IX and IV preponderance of light form, very great deviation $(D=46.66$, with $n=445)$ being found in biotope VIII between the expected and observed value in favour of the dark form, and in biotope IX $(D=63.96$, with $\mathrm{n}=264)$ in favour of the light form (Table 3).

In wet biotopes there are on an average more individuals with cinnamon-coloured fur $(42 \%)$ than in dry biotopes $(32 \%)$ (Table 3$)$. Differences between averages are statistically significant $\left(\chi_{1}^{2}=13.908\right.$; $P<0.001)$. As in the case of occurrence of the light and dark forms, 
among dry biotopes it was only in biotope VI that a smaller number of water shrews of cinnamone colour was found than had been expected, but in the remainder there was predominance and among wet biotopes the predominance of water shrews of cinnamon tinge in relation to expected values was found in biotopes IX and IV, and a minority of this colour in biotopes VII and VIII. Within the wet biotopes differences between each biotope are even greater $\left(\chi_{3}^{2}=272.5 ; P \ll 0.001\right)$ than within the dry biotopes.

\section{Table 3}

Frequency of occurrence in study biotopes of $N$. fodiens with given colour features on ventral side of body. Material from period 1946-1968.

\begin{tabular}{|c|c|c|c|c|c|c|c|c|c|c|c|c|c|c|c|}
\hline \multirow[t]{2}{*}{ Biotopes } & \multirow[t]{2}{*}{$\mathrm{n}$} & \multicolumn{2}{|c|}{$\begin{array}{l}\text { Light } \\
\text { form }\end{array}$} & \multicolumn{2}{|c|}{$\begin{array}{l}\text { Cinnamon } \\
\text { form }\end{array}$} & \multicolumn{2}{|c|}{$\begin{array}{l}\text { Extr. } \\
\text { cin. } \\
\text { form }\end{array}$} & \multicolumn{2}{|c|}{$\begin{array}{l}\text { Extr. } \\
\text { dark } \\
\text { form }\end{array}$} & \multicolumn{2}{|c|}{$\begin{array}{l}\text { Dark } \\
\text { stripe }\end{array}$} & \multicolumn{2}{|c|}{$\begin{array}{r}\text { Dark } \\
\text { spot }\end{array}$} & \multicolumn{2}{|c|}{$\begin{array}{c}\text { Badges } \\
\text { under } \\
\text { fore legs }\end{array}$} \\
\hline & & $\mathrm{n}$ & $\%$ & $\mathrm{n}$ & $\%$ & $\bar{n}$ & $\%$ & $\mathrm{n}$ & $\%$ & $\mathrm{n}$ & $\%$ & $\mathrm{n}$ & $\%$ & $n$ & $\%$ \\
\hline & 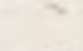 & & & & Dry & bio & topes & & & & & & & & \\
\hline I & 15 & 11 & 73 & 7 & 47 & - & - & - & - & 5 & 33 & 9 & 60 & - & - \\
\hline $\begin{array}{l}\text { II } \\
\text { III }\end{array}$ & 61 & 33 & 54 & 25 & 41 & - & - & 1 & 2 & 15 & 25 & 28 & 45 & 1 & 2 \\
\hline $\begin{array}{l}\text { IIIa } \\
\text { V }\end{array}$ & 22 & 19 & 86 & 18 & 82 & - & - & - & - & 8 & 36 & 10 & 45 & - & - \\
\hline Va & 18 & 16 & 89 & 13 & 72 & - & - & 1 & 5 & 4 & 22 & 9 & 50 & - & - \\
\hline VI & 362 & 167 & 46 & 92 & 25 & - & - & 6 & 2 & 127 & 35 & 190 & 52 & 6 & 2 \\
\hline $\begin{array}{l}\text { Totals } \\
\text { and Avgs }\end{array}$ & 478 & 246 & 51 & 155 & 32 & - & - & 8 & 2 & 159 & 33 & 246 & 51 & 7 & 1 \\
\hline & & & & & Wet & bio & topes & & & & & & & & \\
\hline VII & 222 & 97 & 44 & 63 & 28 & - & - & 1 & .5 & 98 & 44 & 121 & 54 & 1 & .5 \\
\hline VIII & 445 & 213 & 48 & 99 & 22 & 4 & 1 & 7 & 2 & 164 & 37 & 225 & 50 & 8 & 2 \\
\hline IX & 264 & 218 & 83 & 205 & 78 & 3 & 1 & 4 & 1 & 78 & 29 & 133 & 50 & 5 & 2 \\
\hline & 75 & 59 & 79 & 61 & 81 & - & - & 4 & 5 & 28 & 37 & 43 & 57 & - & - \\
\hline $\begin{array}{l}\text { Totals } \\
\text { and Avgs }\end{array}$ & 1006 & 587 & 58 & 428 & 42 & 7 & 1 & 16 & 2 & 368 & 37 & 522 & 52 & 14 & t \\
\hline Total and & & & & & & & & & & & & & & & \\
\hline Averages & 1484 & 833 & 56 & 583 & 39 & 7 & .5 & 24 & 2 & 527 & 35 & 768 & 52 & 21 & 1 \\
\hline
\end{tabular}

There are, however, no great biotope differences in respect of individuals with dark badges. In dry biotopes there were $33 \%$ of the water shrews with a stripe, and in wet biotopes $36 \%$ (Table 3 ). These differences are not significant $\left(\chi_{1}^{2}=1.052 ; P>0.3\right)$. There is also a lack of significant differences in comparisons of different dry biotopes $\left(\chi_{4}^{2}=3.691 ; P>0.3\right)$, but differences were shown to be significant among wet biotopes $\left(\chi_{\mathbf{s}}^{2}=12.753 ; P<0.01\right)$. Among the latter there is a preponderance of individuals with a stripe in biotopes VII and VIII, and a deficiency in relation to expected values in biotopes IX and IV. In relation to individuals with a spot differences were in no case found to 
be significant: when dry and wet biotopes were compared the values $\chi_{1}^{2}=0.024 ; P>0.8$ were obtained, in dry biotopes $\chi_{4}^{2}=1.677 ; P \approx 0.8$, and wet biotopes $\chi_{3}^{2}=2.054 ; P>0.5$.

In conclusion it was found that there are no distinct connections between the type of habitat, i.e. biotope and the colour features considered in the water shrew. Material obtained during the period 1946$1950(n=518)$ may be considered representative and in addition trapping methods were uniform.

\subsection{Differentiation in Time}

In order to consider the changes which have taken place during a period of 22 years of collecting material, individuals were divided into generations (Table 4), then after calculating frequency of occurrence

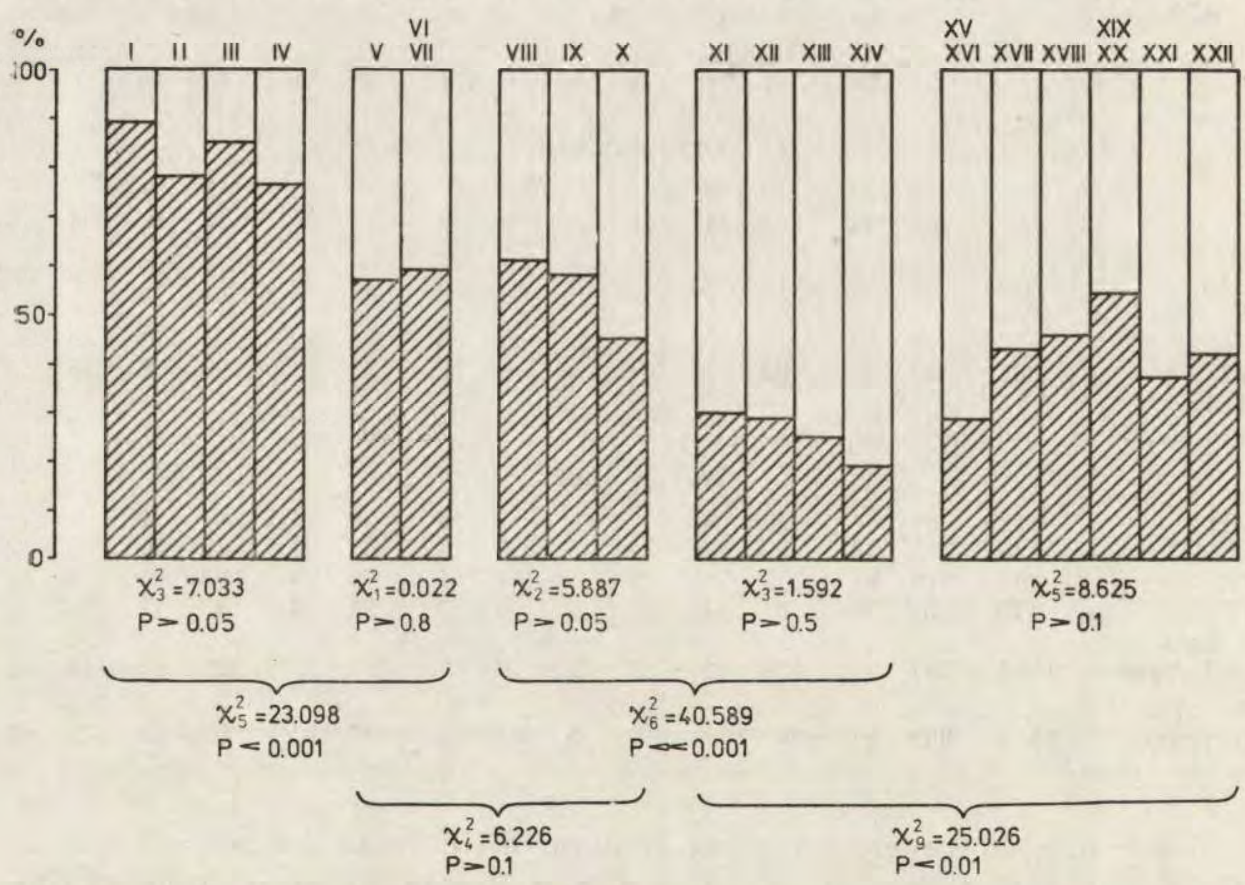

Fig. 2. Percentage formed by light and dark forms of $N$. fodiens in successive generations, and values of test for homogeneity of samples within five groups of generations and between neighbouring groups.

of the features in percentages, adjacent generations possessing similar frequencies of the features considered were combined in groups. Five groups of generations were distinguished (Table 4). It unfortunately proved impossible to arrange groups of generations so that they con- 


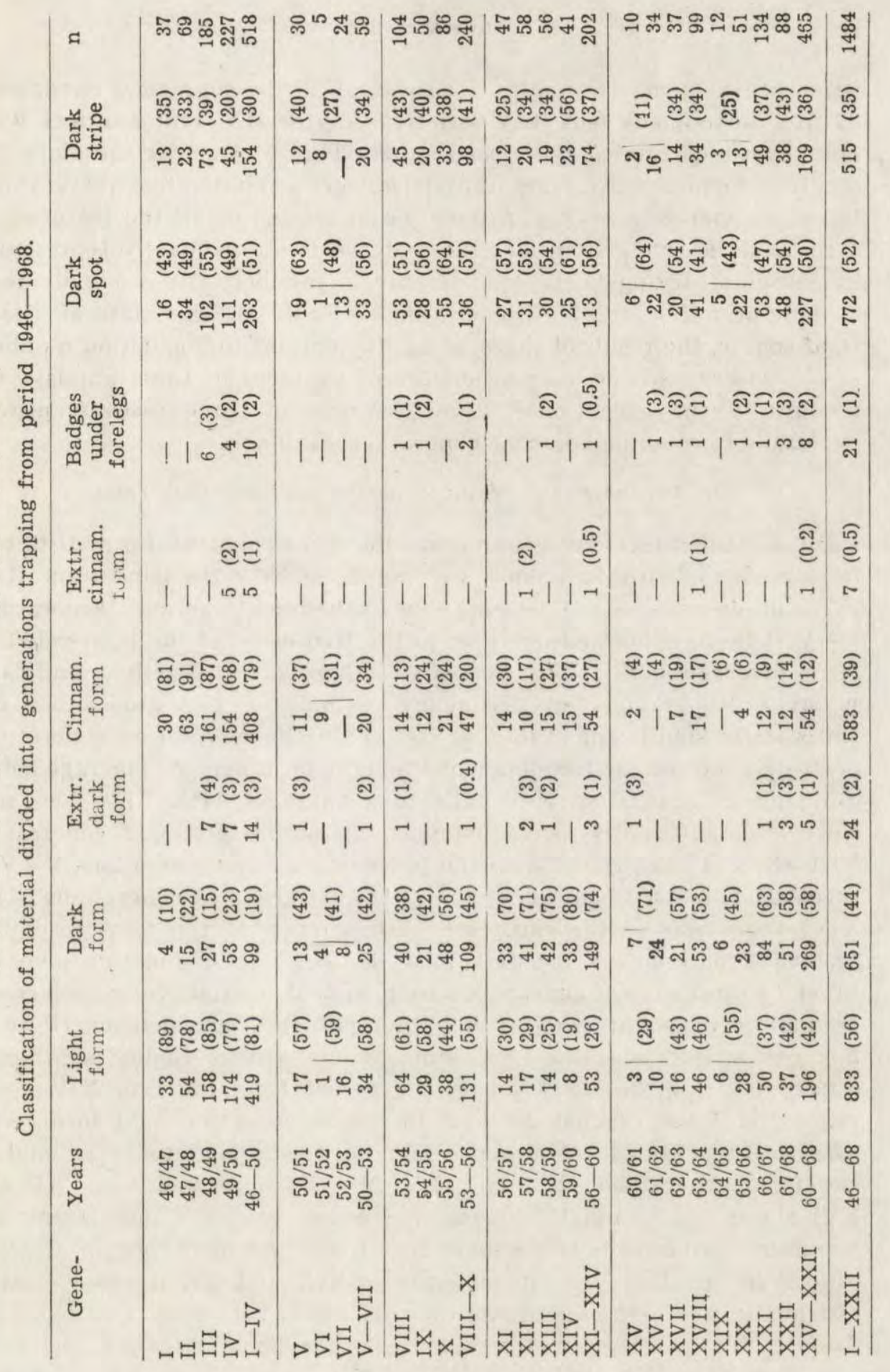


stituted homogeneous samples in respect of all the characters considered, due to the obvious fact that variations in the different features were not always correlated with each other. This division is therefore the result of a compromise: lines of division were so chosen that they formed the most homogeneous groups possible in respect of all the features.

In 22 successive generations the material is unfortunately represented by samples varying fairly considerably in numbers (from 5 individuals in generation VI to 227 in generation IV Table 4). This state of affairs is, of course, the result of there being fluctuations in population numbers of $N$. fodiens and the varying degree of captures of these animals. On account of the exceptionally low numbers in three cases it proved necessary to combine adjacent generations (Table 4).

\subsubsection{Fluctuations in Frequency of the Light and Dark Form}

During the first four generations the light-coloured form distinctly predominates, with frequency varying from $89 \%$ (in generation I) to $77 \%$ (in generation IV). During the subsequent period (generations V-VII) there is marked decrease in the frequency of the light-coloured form (average $58 \%$ ). This decrease is highly statistically significant, whereas fluctuations in frequency within the two groups are not statistically significant (Table 4, Fig. 2). In the next three generations (VIII-X) the similar frequency of the light form persists (average $55 \%$ ), although in generation $X$ it falls to a value of $44 \%$. This does not, however, significantly affect homogeneity within group of generations VIII-X, and comparison with the preceding group (generations V-VII) reveals satisfactory homogeneity. In the next group of generations (XIXIV) there was further decrease in frequency of the light form, individuals representing the dark form distinctly predominating (average $74 \%$ ). In this group of generations frequency of the light form underwent gradual decrease, but even so this group is highly homogeneous $(P>0.5)$, but comparison with the preceding group reveals highly significant differences (Fig. 2). Thus during the period from the I to XIV generation there was gradual decrease in frequency of the light form, with more abrupt jumps occurring twice: between generations IV and V and from generations IX to XI (Fig. 2). As from generations XV and XVI there is a gradual increase in frequency of the light form, the maximum value ( $55 \%$ of the light form) occuring in the group of generations from XIV-XXII in generations XIX and XX (treated jointly) and in the two last generations there is marked decrease in frequency. Despite the fairly great fluctuations in frequency of the light form (extremes $29-55 \%$ ) generations XV-XXII a homogeneous group differing significantly from the preceding group (Table 4, Fig. 2). 
4.2.2. Extremely Dark Water Shrews (Unicolour)

In the Białowieża Primeval Forest the extremely dark (unicolour) form of water shrew is relatively seldom encountered. In the material examined, out of 1484 individuals only $24(2 \%)$ were found. During the initial period (generations III, IV and V) they are slightly more frequent (about $3 \%$ ) (Table 4), nevertheless frequency of occurrence of the extremely dark water shrews does not depend on frequency of the dark form. The highest percentage of unicolour individuals $(7 \%)$ occurs in the class with low frequency of the dark form $(21-30 \%)$, whereas in two classes with maximum frequency of the dark form only $3.06 \%$ and $3.66 \%$ of unicolour water shrews occur. Expected numbers of unicolour

Table 5

Relation between numbers of dark form and numbers of extreme dark form (unicolour) in $N$. fodiens.

\begin{tabular}{|c|c|c|c|c|c|c|c|c|c|}
\hline $\begin{array}{l}\text { Classes of dark } \\
\text { form frequencies }\end{array}$ & -20 & $21-30$ & $31-40$ & $41-50$ & $51-60$ & $61-70$ & $71-80$ & $81-90$ & Totals \\
\hline $\begin{array}{l}\text { Dark } \mathrm{n} \\
\text { form Frequencies }\end{array}$ & $\begin{array}{l}9 \\
0.01\end{array}$ & $\begin{array}{l}58 \\
0.07\end{array}$ & $\begin{array}{l}50 \\
0.06\end{array}$ & $\begin{array}{l}137 \\
0.16\end{array}$ & $\begin{array}{l}97 \\
0.12\end{array}$ & $\begin{array}{l}64 \\
0.08\end{array}$ & $\begin{array}{l}228 \\
0.27\end{array}$ & $\begin{array}{c}191 \\
0.23\end{array}$ & $\begin{array}{l}834 \\
1.00\end{array}$ \\
\hline $\begin{array}{l}\text { Extr. n obs, } \\
\text { dark } n \text { exp. } \\
\text { form } \% \text { of dark from }\end{array}$ & $\overline{0.26}$ & $\begin{array}{l}4 \\
1.67 \\
6.90\end{array}$ & $\begin{array}{l}1 \\
1.44 \\
2.00\end{array}$ & $\begin{array}{l}3 \\
3.94 \\
2.19\end{array}$ & $\begin{array}{l}1 \\
2.79 \\
1.03\end{array}$ & $\begin{array}{l}1 \\
1.84 \\
1.56\end{array}$ & $\begin{array}{l}7 \\
6.56 \\
3.06\end{array}$ & $\begin{array}{l}7 \\
5.50 \\
3.66\end{array}$ & $\begin{array}{l}24 \\
24.00\end{array}$ \\
\hline
\end{tabular}

water shrews calculated on the basis of fractions of dark form approximately agree with the numbers observed, preponderance of extremely dark animals in relation to expected values occurring in three classes $(21-30 \%, 71-80 \%$ and $81-90 \%)$ of frequency of the dark form (Table 5).

\subsubsection{Occurrence of Cinnamon Colour in the Coat of Neomys fodiens}

Frequency of water shrews with coats tinged with cinnamon colour (this is always an additional colour occurring in both the dark and light form) is subject to far greater fluctuations than the variations in frequency discussed above of the dark and light form. During the first period (generations I-IV) the numbers of water shrews with coats tinged with cinnamon colour markedly predominate (average $79 \%$ ) (Table 4). The maximum occurs in the second generation $(91 \%$ of the animals had a cinnamon tinge in their coats). The first more noticeable decrease in frequency occurred in generation IV, which resulted in the group consisting of generations I-IV not being homogeneous in respect of the cinnamon tinge (Fig. 3), while the first three generations form a completely 
homogeneous group $\left(\chi_{2}^{2}=2.299 ; P>0.3\right)$. The second abrupt decrease in frequency of the cinnamon tinge in water shrews occurred in generation $\mathrm{V}$. As from this period the frequencies of this feature are subject to. some degree of fluctuation, but never exceed the value of $40 \%$ (Table 4). On this account the remaining four groups of generations are adequately homogeneous, but differences between neighbouring groups of generations are statistically significant (Fig. 3).

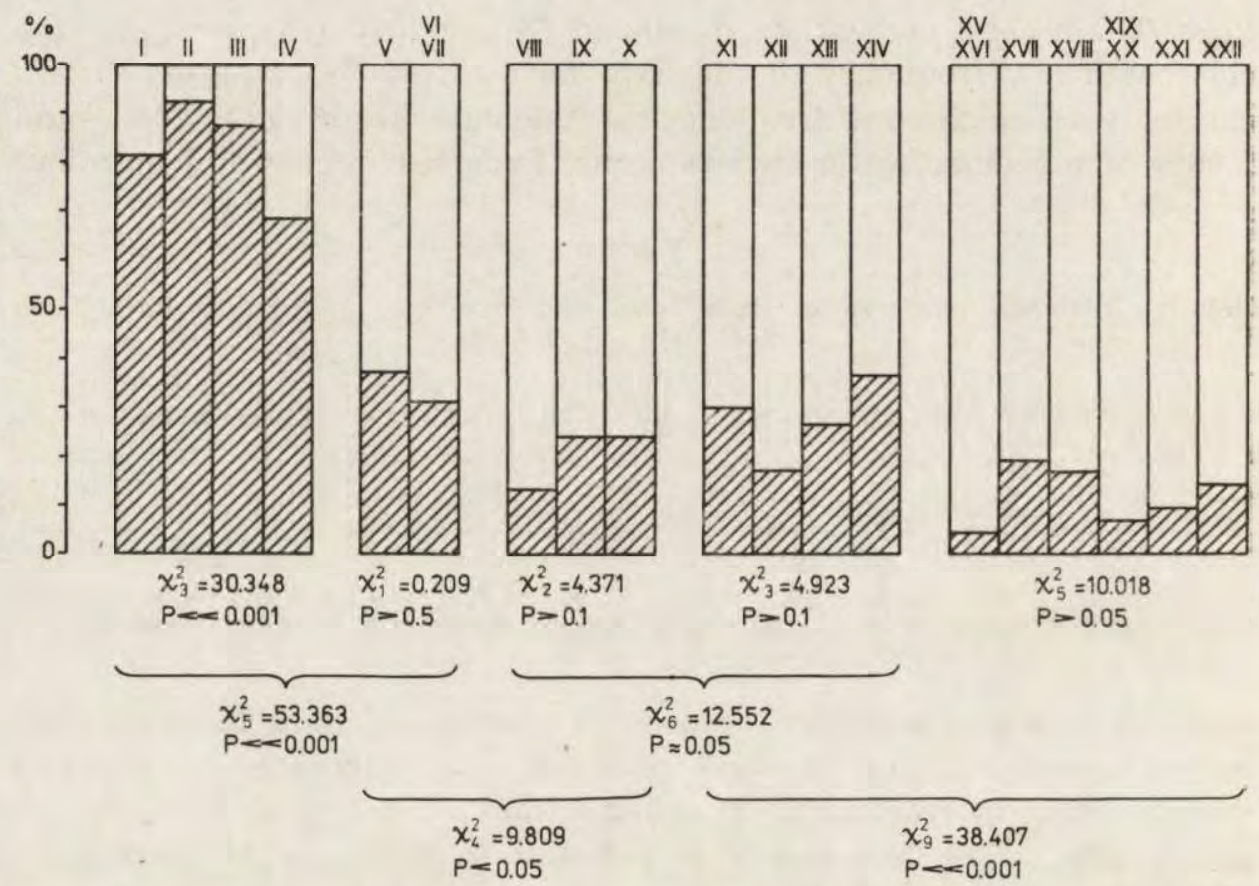

Fig. 3. Percentage of individuals of $N$. fodiens with additional cinnamon tinge in their coats, and values of test for homogeneity of samples within and between groups of generations.

\subsubsection{Extreme Cinnamon Colour in Water Shrews}

Water shrews exhibiting the extreme cinnamon colour occur very rarely in the Białowieża population. Out of the total number of 7 such animals, 5 belong to generation IV, in which frequency of individuals with an additional cinnamon tinge was $68 \%$. The remaining two individuals occurred singly in generations XII and XVII, in which generations frequency of cinnamon-tinged water shrews was in each case $17 \%$ (Table 4). The extreme cinnamon colour in water shrews thus occurs both with high and low frequencies of individuals exhibiting any degree of this colour, but with such low frequencies of extreme cinnamon colour 
that it is impossible to establish whether its occurrence is connected with the frequency with which the cinnamon form occurs in a population.

\subsubsection{Additional Colour Badges on the Ventral Side of Water Shrews}

Dark spots on the throat. The frequency of this character in the first three generations gradually increases from the value $43 \%$ to $55 \%$, but. decreases slightly in the fourth generation. In generation $\mathrm{V}$ the frequency of water shrews with a dark spot reaches an approximately maximum value, followed by the first more distinct decrease in the two subsequent. generations (treated jointly). These frequencies again increase in the

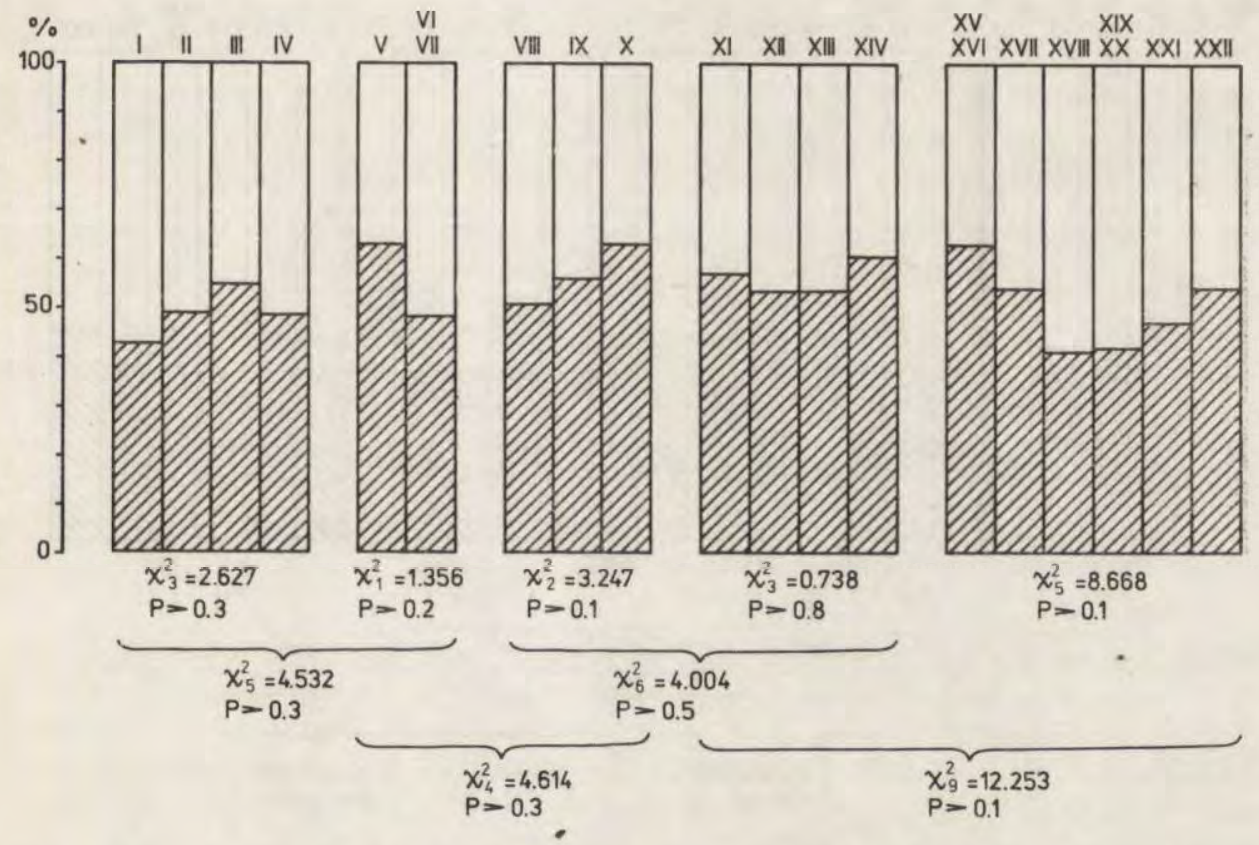

Fig. 4. Percentage of individuals of $N$. fodiens with a spot, and values of test: for homogeneity of samples within and between groups of generations.

three following generations, resulting in maximum frequency $(64 \%)$ : occurring in generation X. In the next two generations (XI and XII) this frequency again decreases slightly, rising once again in generations XIV-XVI. In generations XVII and XVIII there is a second abrupt. decrease in the frequency of individuals with a dark spot, minimal value being reached in this last generation $(41 \%)$, after which there is a gradual increase in frequency (Table 4).

Fluctuations in frequencies of individuals with a dark spot are relatively slight. Differences between extreme values are about $20 \%$, 
and consequently all the five groups of generations distinguished form homogeneous samples, while comparisons of neighbouring groups of generations distinguished form homogeneous samples, while comparisons of neighbouring groups of generations fail to reveal no significant differences (Fig. 4). Within the range of the 22 generations examined frequencies of individuals with a dark spot oscillate round the value $52 \%$ (i.e. total average). It must also be emphasised that fluctuations in frequencies are not steep and consequently average values for the groups of generations are fairly close to the total average (Table 4).

Dark stripe running along the median line of the belly. In the whole

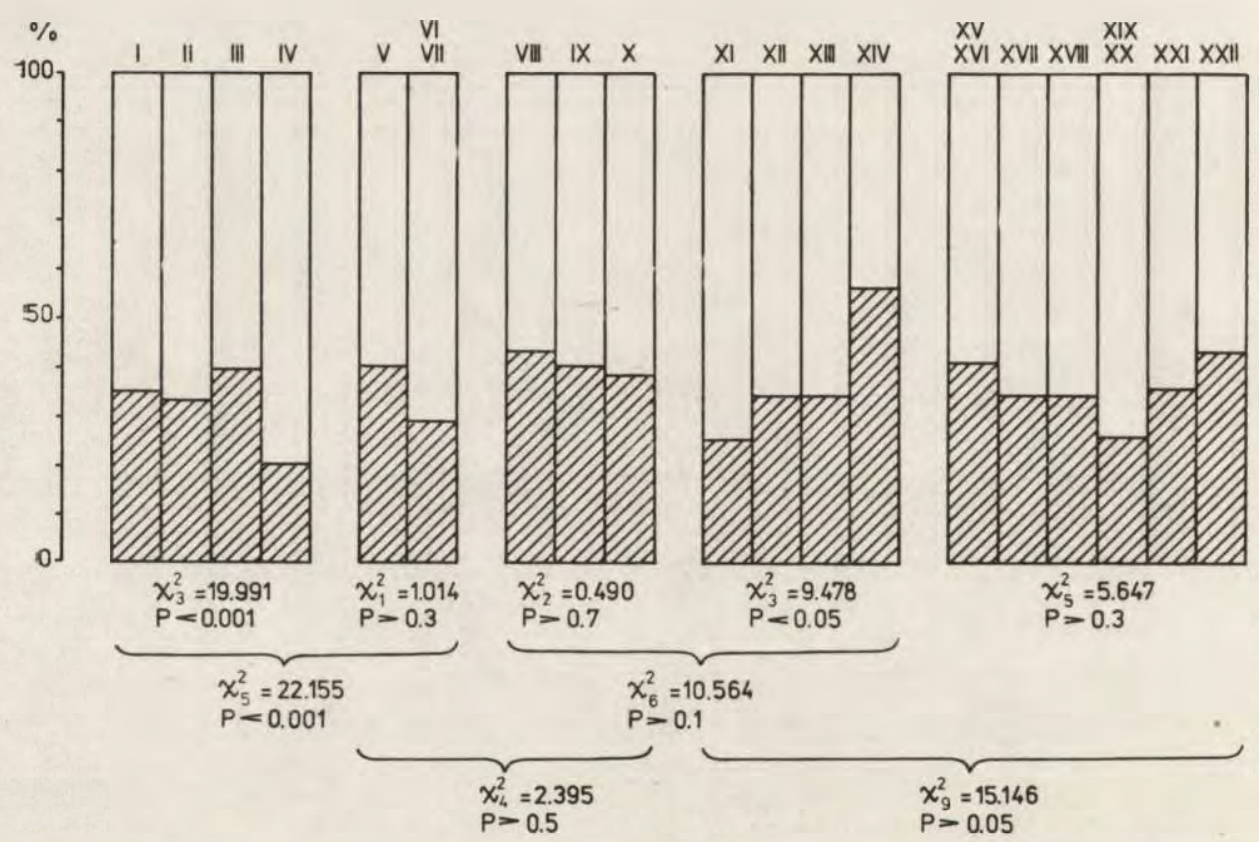

Fig. 5. Percentage of individuals of $N$. fodiens with stripe along belly, and values of test for homogeneity of samples within and between groups of generations.

of the material ( $n=1484) 35 \%$ of the individuals exhibit a stripe. During the period covered by the first three generations the frequencies of this character fluctuate round average values, after which this frequency drops to $20 \%$ in generation IV (Table 4). This decrease causes significant differentiation within groups of generations I-IV (Fig. 5). In the next generation (V) the frequency of individuals with a dark stripe again increases to $40 \%$, but in the two following generations (VI+VII) it again drops to a value of $28 \%$, but the differences are not significant (Table 4, Fig. 5). In generations VIII-X there were high frequencies 
from $43 \%$ gradually decreasing to $38 \%$, and thus generations VIII-X form a highly homogeneous group (Table 4, Fig. 5), while the following group of generations (XI-XIV) is not statistically homogeneous. During this period there was a considerable increase in frequency from 25 to $56 \%$. In the following period (generations XV-XXII) this frequency gradually decreases, but rises again in the two last generations. These fluctuations do not affect the homogeneity of the whole group of generations XV-XXII (Table 4, Fig. 5). Comparison of frequencies between neighbouring groups of generations shows that only the first two groups of generations do not form a homogeneous sample, while satisfactory homogeneity was found in the remaining three cases (Fig. 5).

Dark badges under the fore legs. In the study population these badges occur only rarely. Out of a total of 1484 water shrews only 21 individuals $(1 \%)$ were found to exhibit this characters. Furthermore these badges occupy only very small parts of the skin in individuals of the Bialowieża population (Plates I B, II B). During the study period (22 generations during the period from 1946-1968) the frequencies of this feature are fairly balanced. It was only in the group of generations V-VII that out of 59 water shrews not a single individual was found with these badges. In the other generation groups the frequency of this feature varied from $0.5 \%$ (generations XI-XIV) to $2 \%$ (generations I-IV). It is therefore justifiable to state that during the middle period (i.e. generations from $\mathrm{V}$ to XIV) there were slightly fewer water shrews with these badges than in other generations (Table 4). The small numbers involved made it impossible to test for significance.

\subsection{Spatial Differentiation}

The material composing the first four generations, collected in ten biotopes in the Białowieża National Park, is homogeneous in respect of all characters examined. Consideration is given in this section to the spatial differentiation of these characters in material from the whole period (1946-1968). For this purpose trapping areas situated in the same biotopes and at no great distance from each other were combined into sectors. A total of 12 such sectors was defined (Fig. 6), the sectors lying to the north of the river Orłówka (sectors A-E) consisting of trapping areas which were in operation only during the period 1946-1950. The remaining sectors $(\mathrm{F}-\mathrm{M})$ consisted of trapping areas in operation as from 1951. It must be remembered in this connection that in the sectors lying to the south of the river Orłówka there were no continuous W 
areas were in operation for varying time intervals. An exception to this is area V (sector L), VI (sector H) and VII (sector G), since they were in operation simultaneously with the areas situated to the north of the Orłówka river.

The biotope appurtenance of sectors $\mathrm{A}-\mathrm{E}$ has been discussed in the section relating to material for the period 1946-1950. On the other hand sectors $\mathrm{F}$ and I were situated in the south-eastern part of the Białowieża National Park in sedge bogs along the banks of the Narewka river, sectors $\mathrm{G}$ and $\mathrm{M}$ in floodplain forests, deciduous forest is represented by sector $\mathrm{H}$, while sectors $\mathrm{K}$ and $\mathrm{L}$ are situated in deciduous forest (pure form).

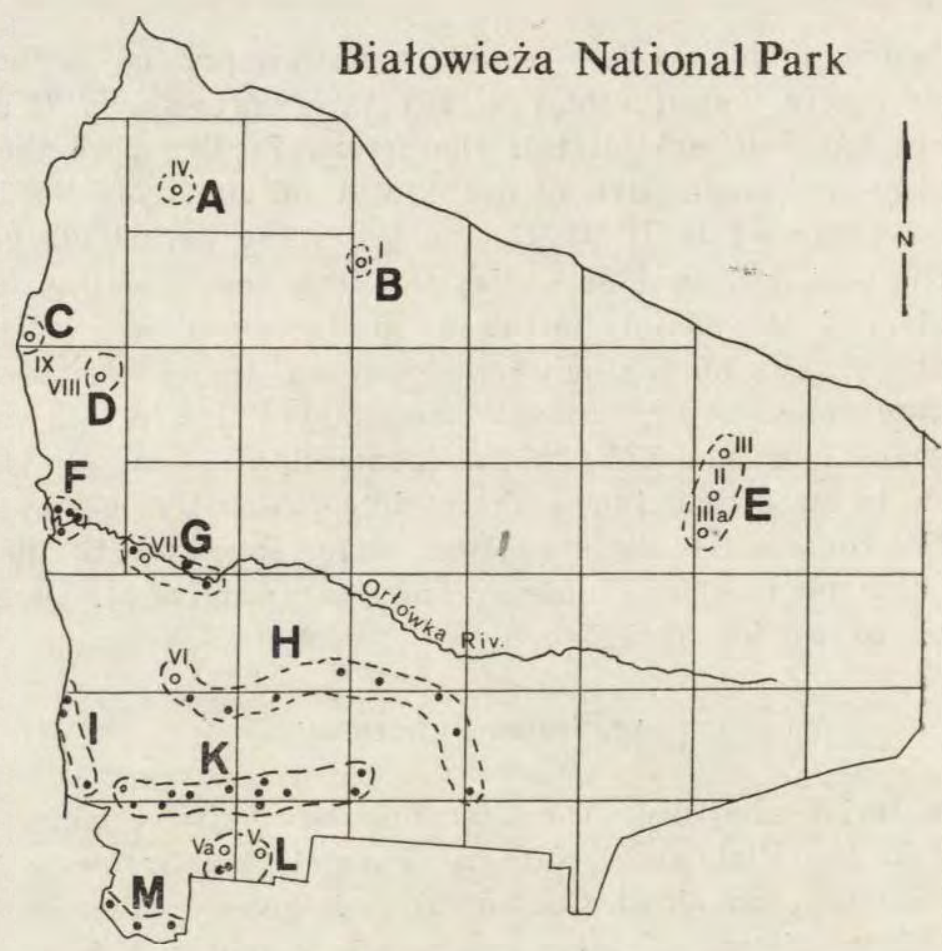

Fig. 6. Map of the Białowieża National Park.

rrapping areas operating during period 1946-1950 indicated by circles giving biotope numbers in accordance with Table 1. Trapping areas operating after 1950 are indicated by black circles. Sectors indicated by dotted line and large letters.

Spatial distribution of frequencies of the light-coloured form exhibits differences are most certainly due to the high frequencies of the lightOrłówka (A-E) far higher values occur than in sectors $\mathrm{F}-\mathrm{M}$. These distinct division into two groups: in the sectors to the north of the coloured form during the initial part of the study period (cf. Fig. 2). In 
sectors $\mathrm{F}-\mathrm{M}$ values are fairly even, differences between sectors with extreme frequencies ( $\mathrm{L}$ and $\mathrm{M}$ ) not reaching as much as $20 \%$ (Fig. 7).

There is far greater variety in frequencies of water shrews with a cinnamon tinge in their coat, and in this case also it is possible to distinguish two groups of sectors. In the northern sectors far greater frequencies of cinnamon-coloured water shrews occur than in the southern sectors, these differences most probably being due to variation in time (cf. Fig. $3)$. Southern sectors $(F-M)$ can also be divided into two groups; sectors $\mathrm{G}, \mathrm{H}$ and $\mathrm{L}$ have higher values $(30-47 \%)$, whereas sectors $\mathrm{F}, \mathrm{I}, \mathrm{K}$ and M have very low values (from 7 to over $20 \%$ ) (Fig. 7).

On the other hand frequencies of water shrews with stripes on the belly are more balanced in all 12 sectors. In the first place there are no distinct differences between the northern and southern sectors, although frequencies are generally slightly lower in the former. It is interesting that in the four sectors situated furthest to the south (i.e. $\mathrm{I}, \mathrm{K}, \mathrm{L}$ and $\mathrm{M}$ ) these frequencies are almost the same (Fig. 7). The

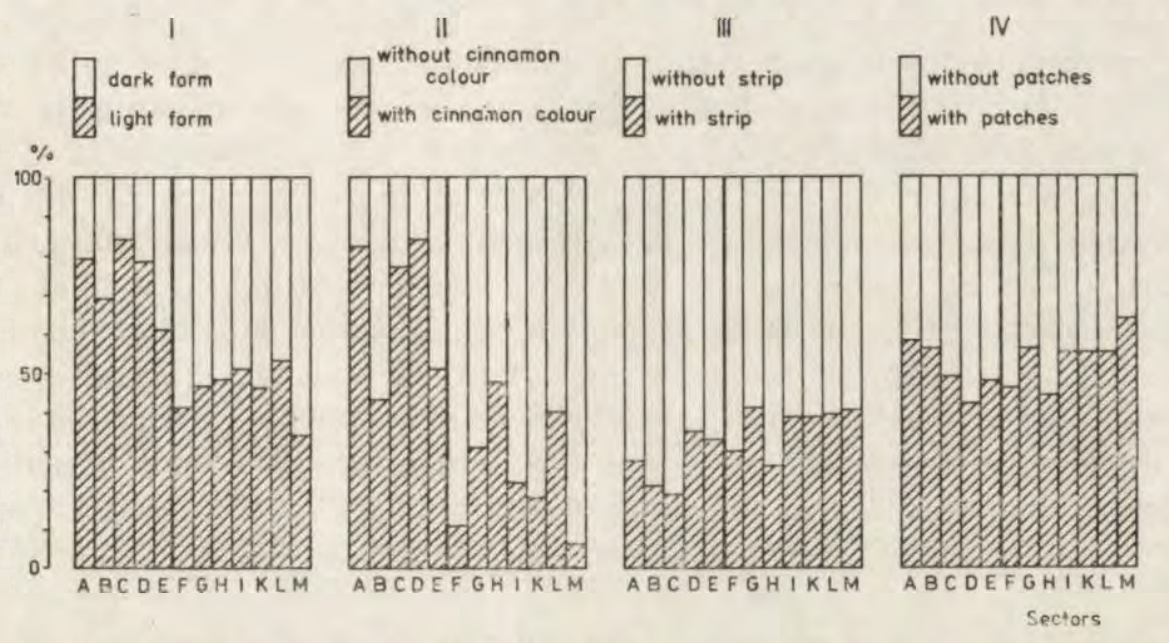

Fig. 7. Percentage in sectors: of light and dark form (I), individuals with coat exhibiting cinnamon tinge and without this colour (II), individuals with and without stripe (III), individuals with and without spot (IV).

situation is similar in respect of individuals with a dark spot, differences between the various sectors being also slight, with no differences between sectors situated to the north and south of the river Orłówka. Three sectors ( $\mathrm{I}, \mathrm{K}$ and $\mathrm{L}$ ) are also distinguished by very similar frequencies of individuals with a dark spot (Fig. 7).

It may therefore be concluded that there are no striking regularities in the spatial distribution of frequencies of the various features. In conclusion it may be stated that no relation was found to exist between 
the coat colour of Neomys fodiens and the habitat, or in spatial differentiation of the population.

\section{DISCUSSION}

Far less is known about the genetic bases of heredity of coat colour in wild mammals than in laboratory animals. Conclusions as to the genetics of their colour are most often reached through analogy, referring to the hypothesis as to the existence of homologous series of genes (V a vilov, 1922). It was accepted on this principle (S e a rle, 1968) that dark dorsal colouring and light ventral colouring in $N$. fodiens is dependent on the black and tan allel (allel $a^{t}$ from a series of agouti). The genetic interpretation of dark patches on the ventral side is far more difficult. K a hm a n n \& R ös s n e r (1956) consider such patches as a dominating feature, basing their conclusion on three $F_{1}$ individuals obtained from crossing a female with a white belly with a male with a spotted belly. The progeny had spots on the belly. In litters born at Białowieża, however (D e hne l, 1950; M i chalak \& Borowski, in preparation), there were water shrews with and without spots on the belly, despite the fact that at least one of the parent animals was a spotted specimen. It must be remembered in this connection that the presence of spots in the Białowieża population is far more weakly expressed than in populations from the west of Europe, which may affect the results of crossbreeding $N$. fodiens, and also indicates that the presence of spots is probably dependent on multiple genes. The melanistic form (in this paper termed extreme dark or unicolour) would appear to be phenotypically non-agouti ( $a a)$ (S e a r l e, 1968).

In view of the foregoing it was found that the dichotomic classification of individuals with dark badges introduced in the present paper does not produce genetically homogeneous groups. Most certainly individuals in which a given feature is absent (spots, stripes or badges under the fore legs) are more homogeneous genetically than individuals possessing these features, since each of such badges may occupy a small or large area of the skin.

In relation to the cinnamon tinge, Dehnel (1950) found that this tinge can be wiped off with a damp cloth, but did not slove the question as to wheather this is a mineral stain ${ }^{2}$ or is of organic origin. $\mathrm{K}$ a hmann \& Rössner (1956) incline to the second opinion. They found that the coat in water shrews kept in captivity after moulting did not regrow hair with a cinnamon tinge. This was not found in respect of the Białowieża material kept in the laboratory (M i c hal a k \& B o-

2 Dehnel (1949) fund that the ur of Sorex araneus originating from wet biotopes was soiled with limonite r:e. 
row ski, in preparation). Ka h m a n n \& R ös s n e r (1956) consider that this is a colour from the carotenoid group and reaches the organism together with the animal's food. They suggest that Gammarus, the abundant appearances of which coincided with greater frequency of water shrews with a tawny (cinnamon) tinge, might supply these carotenoids. Observations of litters born in the laboratory of the Mammals Research Institute refute this view: one of the young water shrews had a cinnamon tinge. The present study did not provide confirmation of the suggestion that water shrew with coats tinged with cinnamon occured more often in wet biotopes. Although water shrews with an extreme cinnamon tinge were caught only in wet biotopes, this in most probably due to samples greatly differing in numbers being obtained from wet and dry habitats. The absence of significant differences in frequency of water shrews with a cinnamon tinge, originating from varied biotopes (material for period 1946-1950), indicates that this colour is not due to soiling with limonite. It is difficult to put forward any opinion as to whether this colour reaches the organism together with food and as to its origin without carrying out the relevant experiments.

The features of mammals' colouring were often connected with their habitat. R e in ig (1937) found that animals occurring in a damp habitat are in general of darker colour (bog melanism). L e h mann (1966) in comparing individuals originating from marshy and dry areas distant from each other, confirms the existence of bog melanism in Neomys fodiens, the author connecting the presence of spots with melanism. No significant differences were found in the present study between wet and dry biotopes in relation to dark badges (material for period 19461950). Marked differences occurred after material from subsequent years is added. In this case fluctuations in the frequency of these features over the whole study period of 22 generations were superimposed on biotope variation. The melanistic form (i.e. unicolour) is however very rare in the Białowieża population, appearing in dry and wet biotopes with the same frequency (about $2 \%$ ).

It would therefore appear that the colour of $N$. fodiens, both,in relation to the presence of melanin and carotenoid colours, is not connected with the habitat. The absence of significant differences in material from varied habitats may also be due to the fact that the Białowieża Primeval Forest forms a mosaic of biotopes, and it is therefore possible that constant migration of animals between biotopes may be an important factor. It is, however, significant that even comparisons of biotopes prefered by water shrews with those in which these animals occur only sporadically do not reveal significant differences. The division of biotopes into two classes (wet and dry) did not permit of grasping differentiations. 
Differentiation in the features examined over a period of 22 generations is, however, fairly great, fluctuations in frequency taking place gradually, so that it is possible to distinguish periods of relative stabilization of frequency of the features. More abrupt jumps in frequencies (far greater in the case of dark or light-coloured forms and those with a cinnamon tinge, than in the case of spots and stripes) occur in neighbouring generation. It may be concluded that fluctuations in population number of $N$. fodiens affect these variations in frequencies. It is an interesting fact that the frequency of spots is far more variable than frequency of stripes, and on these grounds it may be concluded that these two features are inherited independently of each other.

The absence of relations between the frequency of the dark form and occurrence of melanistic individuals is not surprising, since these two characters are most probably also inherited independently of each other.

Interpretation of spatial differentiation in the features examined (i.e. division of the material into sectors) is also difficult, as variations in time overlap. The more distinct differences relating to frequencies of dark and cinnamon-tinged forms between sectors situated to the north and south of the river Orłówka may also be due to such causes.

The review has for long been held by systematicians that in respect of coat colour the water shrew is greatly differentiated over the whole area of the species' occurrence. This was the reason why so many "species" have been deșcribed (chiefly during the 19th century). These forms were next degraded to the rank of synonyms, or colour variants, or geographical races (Kuntze, 1935). As Dehnel (1950) and Borowski (1973) have shown, all possible colour variants of $N$. fodiens occur in the Białowieża Primeval Forest. This does not of course refute the existence of considerable geographical differentiation. Thus it would appear that dark badges are more frequent and more distinct in certain Western European populations, for example in populations from Germany (Kahmann \& Rössner, 1956), from the French Ardennes (van L a a r \& D a a n, 1976). In the Neusiedlersee district, on the other hand, these features are expressed in a similar way to that in the Bialowieża population: spots are small and stripes very narrow, as far as can be gathered from the diagrammatic drawings included in the paper by $\mathrm{B}$ a u e $\mathrm{r}(1960)$. In this population individuals belonging to the lightcoloured form without spots predominate. Corbet \& Southern (1977) consider that water shrews occurring in England do not differ from the continental forms, but these authors do not refer to the existence of dark badges and the presence of the cinnamon tinge in British water shrews. They give the interesting information that water 
shrews from the island of Shuna are more homogeneous than those occurring in England (C or b e t \& $\mathrm{S}$ o u the rn, 1977).

$\mathrm{K} \mathrm{un} \mathrm{tze} \mathrm{(1935)} \mathrm{had} \mathrm{at} \mathrm{disposal} \mathrm{series} \mathrm{of} \mathrm{water} \mathrm{shrews} \mathrm{caught} \mathrm{in} \mathrm{the}$ Podole and Orawa districts (now in the Soviet Union), but does not refer in his description of coat colour of Neomys fodiens to the existence in these populations of additional colour features, and they must therefore have been rare, since Kuntze gives a very detailed description of coat colour in $N$. fodiens. There are also no references to the existence of the cinnamon tinge in the coats of water shrews from those populations.

Melanism would appear to occur more frequently in Western European populations (G i b a n, 1956; Le h m a n n, 1966), although on account of the scanty material in the papers referred to, any comparisons are out of the question. This also applies to the other papers referred to here, and therefore comparisons made above are far from exact. Comparative studies based on more numerous series of individuals would undoubtedly prove interesting.

Acknowledgements: We should like to thank Dr. A. Yablokov (Institute of Developmental Biology, Moscow) for suggesting the subject of this study and also for the interest shown by him in the progress of work during his visit to Poland. We are particularly indebted to Dr. A. Ruprecht (Mammals Research Institute, Bialowieża) for his unfailing interest in the progress of our studies and for his helpful suggestions as to literature dealing with the subject.

\section{REFERENCES}

1. B a u e r K., 1960: Die Säugetiere des Neusiedlersee-Gebietes. Bonn. zool. Beitr., 11: $141-344$.

2. B orowski S., 1973: Variations in coat and colour in representatives of the genus Sorex L. and Neomys Kaup. Acta theriol., 18: 247-279.

3. Borowski \& Dehnel A., 1952: Materiały do biologii Soricidae. Annls. Univ. M. Curie-Skłodowska, C, 7: 305-448.

4. Bree P. J. H. van, Chanudet F. \& Saint Girons M. C., 1963: Notes sur des colorations anormales chez les musaraignes (Insectivora, Soricidae). Mammalia, 27: 300-305.

5. CorbetG. B. \& S outhern H. N., 1977: Handbook of British mammals. 2nd ed., Blackwell Sci. Publ.: 1-520. Oxford.

6. De hne 1 A., 1949: Studies on the genus Sorex L. Annls Univ. M. Curie-Skłodowska, C, 4: 17--102.

7. Dehnel A., 1950: Studies on the genus Neomys Kaup. Annls Univ. M. Curie-Skłodowska, C, 5: 1-63.

8. Giban J., 1956: A propos de la capture de deux crossopes aquatiques aux environs de Versailles. Mammalia, 20: 57-65.

9. Kahmann H. \& Rössner F. X., 1956: Die Natur der Färbungsvielgestaltigkeit der Unterseite bei der Wasserspitzmaus (Neomys). Naturwissenschaften, 43: 46 .

10. Kuntze R., 1935: Ssaki (Mammalia), Zeszyt 2. „Fauna słodkowodna Polski”. Wydawnictwo Kasy im. Mianowskiego. Warszawa. 
11. L a a r V. van \& Da a n N., 1976: Neomys anomalus Cabrera, 1907, observé dans les Ardenmes français. Lutra, 18: 44-51.

12. Lehmann E. von, 1966:Anpassung und "Lokalkolorit" bei den Soriciden zweier linksrheinisches Moore. Säugetierkdl. Mitt., 2: 127-135.

13. Michalak I. \& Borowski S., (in preparation): Uwagi o ubarwieniu Neomys fodiens urodzonych $\mathrm{w}$ hodowli laboratoryjnej.

14. Reinig W., 1937: Melanismus, Albinismus und Rufismus. Georg Tieme Verlag. Leipzig.

15. S e a r le A. G., 1968: Comparative genetics of coat colour in mammals. Logan Press Ltd.: XII+1-308. London.

16. Skaren U., 1973: Aberrant colour of shrews (Sorex araneus L. and Neomys fodiens Schreb.) in Finland. Säugetierk. Mitt., 21: 74-75.

17. Vavilov N. J., 1922: The low of homologous series in variation. J. Genet., 12: $47-89$.

Accepted, October 17, 1979.

\section{Stanisław FEDYK i Stanisław BOROWSKI}

\section{WARIANTY UBARWIENIA RZĘSORKA RZECZKA W BIAEOWIESKIEJ POPULACJI}

\section{Streszczenie}

Analizie poddano 1484 okazy Neomys fodiens lowione w latach 1946-1968 (Tabela 1) i zbadano ubarwienie brzusznej strony ciała (Ryc. 1). U rzęsorków pochodzących z różnych zespołów leśnych stwierdzono niewielkie różnice frekwencji cech barwnych (Tabela 2), natomiast większe różnice występują przy porównaniu kolejnych 22 pokoleń (Tabela 4, Ryc. 2). Frekwencja rzęsorków posiadających domieszkę koloru cyn’monowego waha się znacznie (Tabela 4, Ryc. 3) a udzial osobników z ciemnymi piętnami jest stabilniejszy (Tabela 4, Ryc. 4, 5). Przestrzenny rozkł d frekwencii cech barwnych wskazuje na pewne różnice między sektorami północnymi a południowymi (Ryc. 6, 7). Analiza danych wskazuje na skomplikowany charakter dziedziczenia cech barwnych.

\section{EXPLANATIONS OF PLATES}

The skins of Neomys fodiens.

Plate I

A. Light form without any badges.

B. Light form with dark spot on the throat (sp), dark stripe along median line of the belly (st) and dark badges under the fore legs (bg).

C. Dark form with spot (sp) and stripe (st).

D. Extremely dark form - unicolour.

\section{Plate II}

A. Light form with spot (sp) and stripe (st).

B. Light form with the all three badges on the belly.

C. Light form with stripe (st) only.

D. Light form with spot (sp) and badges connected with the stripe (bg + st). 
ACTA THERIOLOGICA, XXV, 1.

Plate I.

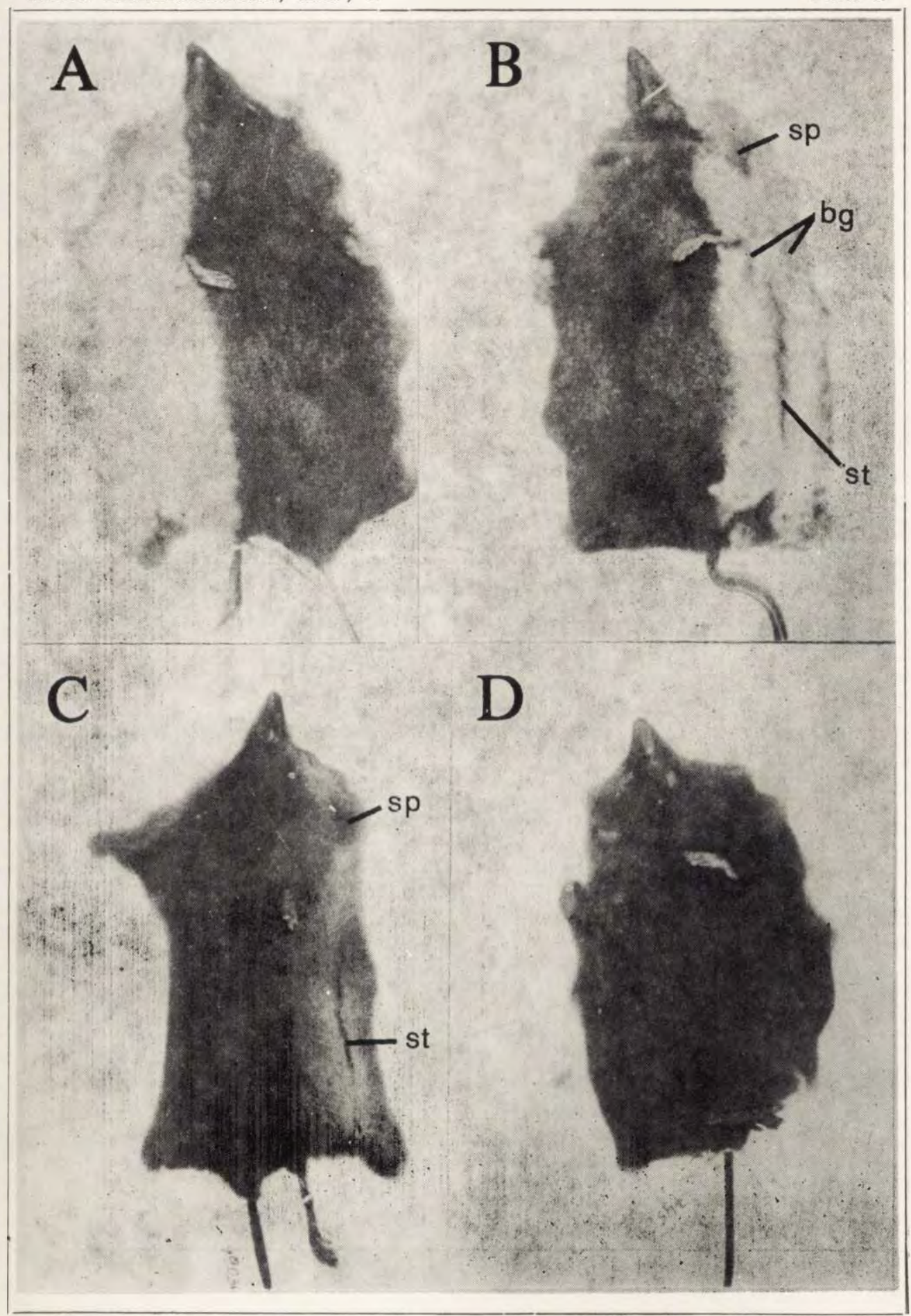

S. Fedyk \& S. Borowski Auctores phot. 


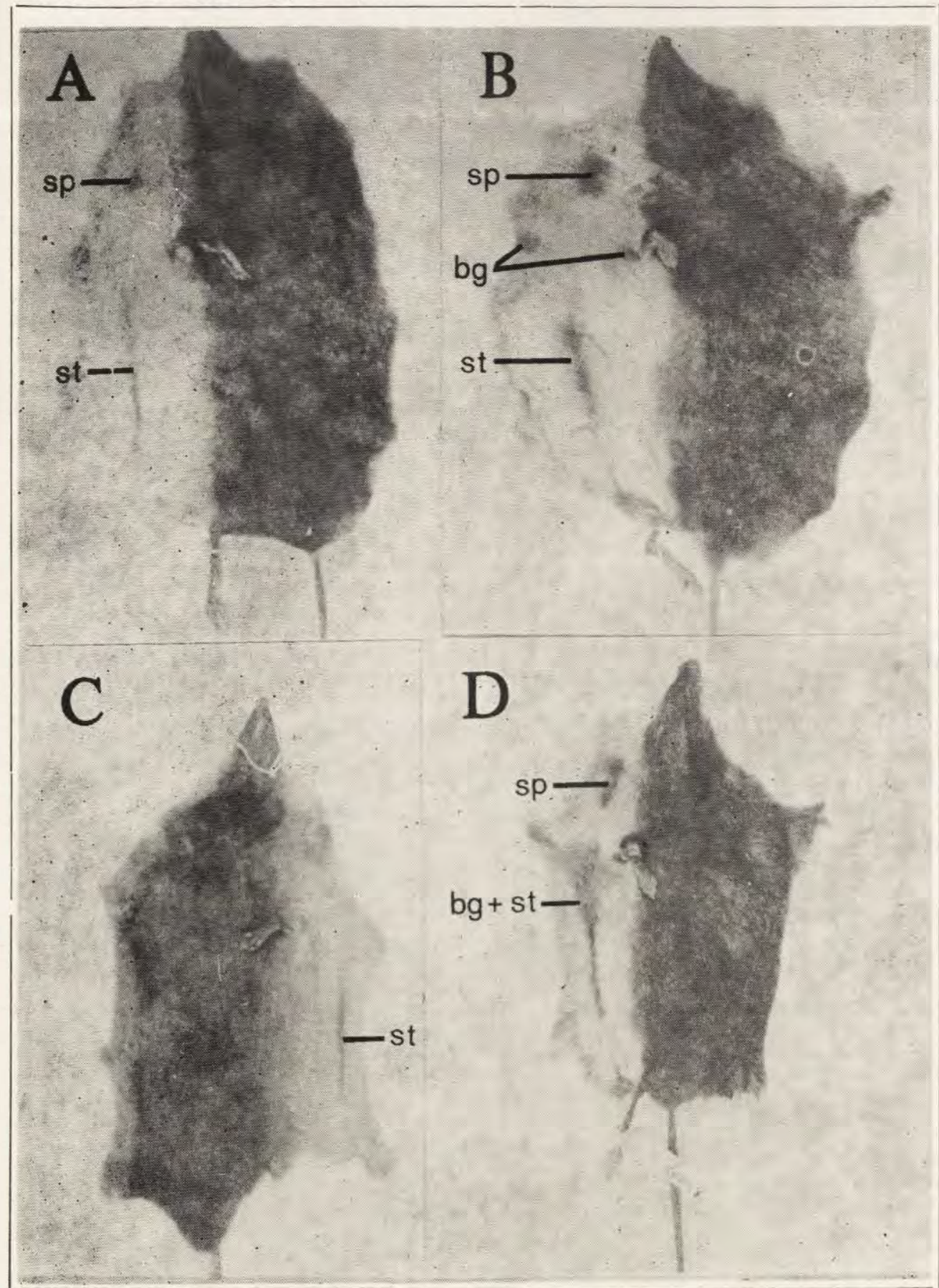

S. Fedyk \& S, Borowski

Auctores phot, 